\title{
The European Teacher: Transnational Perspectives in Teacher Education Policy and Practice
}

Michael Schratz ${ }^{1}$

$\approx$ The future role of teachers in Europe will contribute to raising the awareness of a new expectation of what it means to be a "European Teacher". If there is unity in diversity through national identities, the question remains: what makes a teacher "European"? Answering this unusual question, one encounters several aspects that have strong national traits of what it means to teach in a particular country (e.g. political culture), which still does not enable teachers to easily move their employment from one country to another because of differences in career structure, teacher education, selection and recruitment, etc. However, there are many similarities in general teacher competences that are required throughout Europe and beyond. This paper looks at teacher professionalism from various perspectives, attempts to discern the "Europeanness" in teachers' work and mobility as a goal, and highlights particular policy development areas necessary to stimulate further discussions. The depiction of a European Doctorate in Teacher Education concludes the paper.

Keywords: teacher professionalism, European dimension, mobility, teacher education and competences, teacher education policies

1 Dept. of Teacher Education and School Research, University of Innsbruck, Austria; michael.schratz@uibk.ac.at 


\section{Evropski učitelj: nadnacionalni pogled na politike in prakse izobraževanja učiteljev}

Michael Schratz

\& Vloga učiteljev v Evropi bo v prihodnosti pomembna tudi pri dvigovanju zavedanja o tem, kaj pomeni biti »evropski učitelj«. Čeprav smo si edini, da med državami obstaja raznovrstnost, ostaja vprašanje, kaj naredi učitelja »evropskega«. Pri odgovarjanju na to nenavadno vprašanje lahko naletimo na več različnih vidikov, ki so močno nacionalno zaznamovani, in sicer $\mathrm{s}$ tem, kaj pomeni poučevati $\mathrm{v}$ določeni državi (kot na primer politična kultura). Prav to - razlike v zaposlitveni strukturi, izobraževanju učiteljev, selekciji in v zaposlovanju itn. - učiteljem še vedno ne omogoča, da bi se brez težav zaposlovali v različnih državah. Vendar obstaja veliko podobnosti v generičnih kompetencah učiteljev, ki so zahtevane v vsej Evropi in tudi drugje. Prispevek z različnih vidikov predstavlja profesionalizem učitelja, skuša zaznati »evropskost « učiteljevega dela in mobilnost kot cilj ter poudari določene politike, katerih razvoj bo pomemben pri spodbujanju nadaljnjih razprav. Prispevek se konča $\mathrm{s}$ predstavitvijo evropskega doktorata $\mathrm{v}$ izobraževanju učiteljev.

Ključne besede: profesionalizem učitelja, evropska dimenzija, mobilnost, izobraževanje učiteljev in kompetence, politike s področja izobraževanja učiteljev 


\section{Introduction}

In many ways, Europe has become an increasingly important reference point in the field of education, ranging from exchange programmes at the school level to policy development initiatives across Europe (Bauer \& Ortner, 2008). While in the economy the influence of the European Union on national policies can be traced in everyday encounters, in education national policymaking has been safeguarded against excessive "Europeanization" (Heidenreich, 2014). Although many teachers work within a European context through exchange programmes and other transnational activities, we know very little about their "Europeanness", i.e. what constitutes a teacher within an understanding of European professionalism.

The first discussions on this topic started during a meeting in the European Network on Teacher Education Policies (ENTEP), which was formed at the initiative of the Portuguese minister of education in 1999 and has offered a transnational space for intensive debate concerning critical teacher education policy issues. During the first meeting, the question was asked "Does something like a European teacher exist?" and attendees seemed to be puzzled by the expectations of such a concept. "Do you want to create a standardized teacher model within Europe?" or "Should we give up our sovereignty of the individual member states of the European Union?" were only two of the many questions giving voice to anxieties of too much influence on educational matters on the national level with reference to the field of tension between transnational integration and national disintegration within European society (Münch, 2008).

Since then, the question "What is a European teacher?" has opened up room for further discussions about future roles of teachers in Europe and has contributed to raising awareness for a new expectation of what constitutes a European teacher, i.e. a teacher working within a European context of professionalism. Since its foundation in 1999, ENTEP has created a "European space" that develops opportunities for country representatives to learn from other members on teacher education policies (Valenčič Zuljan \& Vogrinc, 2011), by analysing and comparing policies and issues, as well as by sharing good practices through different kinds of activities. The network uses an open frame of reference for informal exchange and shares knowledge on the basis of written and oral presentations related to specific challenges and issues on teacher education policies. ${ }^{2}$ Among the topics covered were research-based teacher education, induction, teacher evaluation, quality assurance, continuous profes-

2 For further information, see: http://entep.unibuc.eu/. Parts of this article were first published in Schratz, 2010. 
sional development of teachers in EU member states, and others (see Gassner, Kerger, \& Schratz, 2010). Although the Lisbon Strategy of the European Union influences national policies in many ways, creating unity in diversity through national identities, the question remains: what makes a teacher "European"?

\section{Teacher competences in a national context}

If we examine teacher professionalism in general, we come across research findings that expound on the complexity of teaching and teacher education. The historical overview of the advances of the past thirty years in research on teaching in Craig, Meijer, and Broeckmans (2003) highlight traits such as self-awareness and reflection, professionalism in dealing with diversity and uncertainty, collaboration, and cultivating the teachers' image, which seem to be cross-competences that a teacher should acquire. They read like variations of the following criteria from an Austrian research project EPIK 3 , which worked on a concept for professionalism in teaching, taking into account the increasing international context of the education area within an international perspective (Schratz, Paseka, \& Schrittesser, 2011). The findings of the research by representatives from universities, university colleges of teacher education and school inspectorates in Austria were summarized under the umbrella of the following framework of five domains of teacher professionalism.

\section{Reflection and Discourse}

Sharing knowledge and skills refers to the capacity of regarding oneself and one's environment with emotional involvement and with a critical and detached eye, as well as the ability to analyse one's actions in a systematic way from different perspectives (practical experiences, theories of education, methodology, one's own biography, etc.), and the ability to develop alternative strategies accordingly. The language for discourse requires the ability to be focused and to see things clearly by putting them into words, to be able to use a shared language for communication among colleagues.

\section{Professional Awareness}

To experience oneself as an expert refers to the realization of what makes a teacher's work a profession in its own right. The knowledge of one's own ability and expertise in a clearly defined field and the ability to switch from

3 "Entwicklung von Professionalität im internationalen Kontext". A research project initiated by the Federal Ministry of Education and Culture in 2005 developing a framework for professional competences for Austrian teachers within an international context. 
involvement to analysis requires beneficial organizational structures in schools, sufficient scope for professional development, and career options.

\section{Collaboration and Collegiality}

The productivity of cooperation encourages professionals to intensify collegial dialogue, to appreciate and make use of the professional community as a place for communication and collaboration, and to deepen social skills for dealing with colleagues. Collegiality asks for new organizational formats, i.e. structures that promote a culture of openness, as well as for time and place for professional collaboration.

\section{Ability to differenciate}

The ability to deal with differences large and small encompasses the realization of the different learning dispositions of students, the knowledge of how to deal with different learning styles, with communication and integration difficulties, and the skills of personalized learning. It requires practices that help to use "diversity" as a resource and to create an institutional framework for dealing with heterogeneity.

\section{Personal Mastery}

Continuous reflection on experience creates a sense of mastery by building on the principles and practices that follow a personal vision. The power of individual prowess shows (through clear ideas about one's personal objectives) the ability to use one's knowledge and skills adequately in a specific situation as well as to link theory with practice in finding one's own way in strategic development. Personal mastery requires structures that allow and accept mistakes and make genuine personal learning possible and gratifying.

The five domains focus on cross-cutting issues, which strongly characterize professional attitudes and practice, although research shows that the dimensions are less distinctive in teaching practice. The five domains can be described as a classification of competence areas for the teaching profession, theoretically independent of subject matters or school types. However, in practice, the related-to-school types, subjects and their specific didactics are prevalent, and termed the "sixth discipline" within the EPIK concept. "It is the discipline that integrates the disciplines, fusing them into a coherent body of theory and practice" (Senge, 1990, p. 12). The sixth discipline forms the context in which the domains appear. 


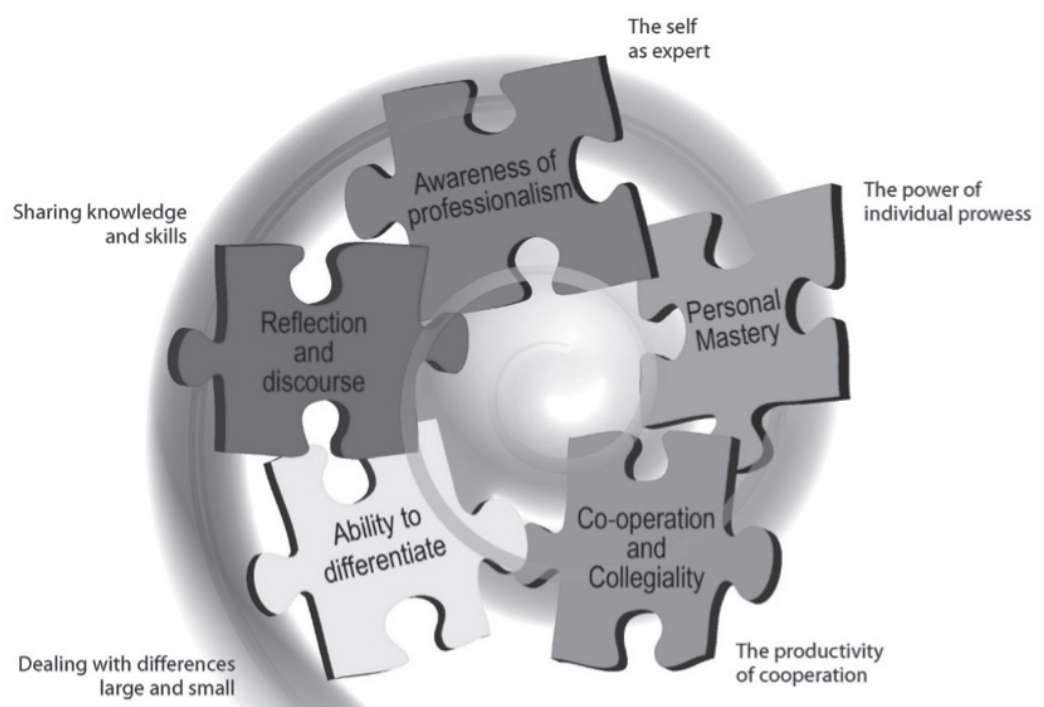

Sixth discipline

Figure 1. The five domains of professionalism and the sixth discipline (from Schratz, Paseka, \& Schrittesser, 2011, p. 26).

For example, the context-specific aspects of teaching refer to the type of school, the subject area taught with the methods involved in practice. In Figure 1, the sixth discipline is shown in the form of a spiral, which indicates that the five domains have relevance for all aspects of the context on different levels. The puzzle shows the multi-perceptivity of the domains, symbolizing their inter-relation and overlapping. Therefore, dealing with difference might occur differently in a math class on the primary level, from differentiation on the upper secondary level or in a different subject such as physical education. The subject matter taught plays a significant role in this understanding of context, since recent research studies show that teachers must have profound knowledge of her/his subject area and the skills to teach students ${ }^{4}$ successfully. Since a teachers' knowledge and skills depend on their continuous learning and development, they should deal with current research and be aware of the individual and social changes. Change forces play a vital role on all levels of the education system. Therefore, the European Union has installed particular working groups with a view towards a common transnational understanding, which will be dealt with in the following section.

4 In this paper, the terms "pupils" and "students" are used interchangeably. 


\section{The European Union's perspective}

Whereas national research and development projects, such as the Austrian one presented in the previous section, build on the knowledge and experiences within a particular socio-cultural context, the European perspective is not in the foreground.

Within the EU, among others, an Expert Group of Teacher Education was installed as a response to issues of student intake, teaching environment, and contextual factors including general social trends and developments in the labour market. Its members were asked which changes in teachers' competences were formally required of teachers in their countries in recent years. They were also invited to identify possible changes that were likely to be required by teachers in the coming years in response to student intake and other issues mentioned above. The following items were summarized by this expert group in a synthesis report. ${ }^{5}$

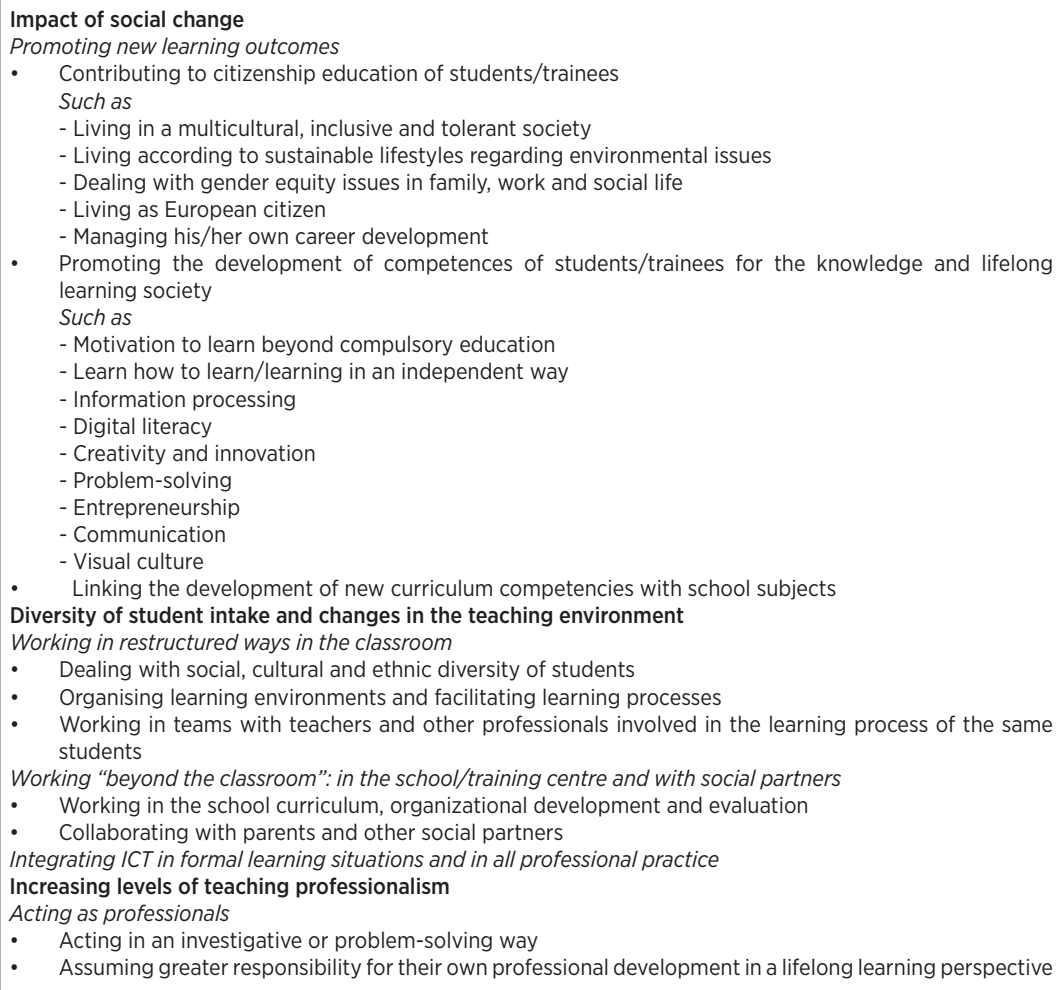

- Assuming greater responsibility for their own professional development in a lifelong learning perspective

Figure 2. Changes in teacher and trainer competences. Synthesis report EU Expert Group on Teacher Education (2003).

5 See Synthesis report of the first homework of the Expert Group on Objective 1.1: Improving the education of teachers and trainers (WG1.1/02/o02). 
This (by no means complete) list indicates essentially general (new) competences required by any (future) teacher. The European dimension is mentioned under citizenship education for students under the heading of "Promoting new learning outcome", but does not appear under "Increasing levels of teaching professionalization". Therefore, ENTEP started a discussion among the member countries' representatives on the question of what "Europeanness" could comprise in teacher professionalism in the European Union with a particular view on mobility within the European education area and suggestions for policy-making implementation (Snoek, Uzerli, \& Schratz, 20o8).

\section{"Europeanness"}

Teachers in the European Union not only educate future citizens of their particular member state, but also support them in becoming future generations of European citizens. They work within a national framework, which emphasizes the need for a national identity as a basis for transnational awareness within European society. The term "European Dimension" has been used to balance national and transnational values in educational policy making.

The discussion on the European teacher goes further by looking closer at what constitutes the "Europeanness" in the teaching profession. From this perspective, the European dimension is composed of many different facets deeply rooted in the socio-political and cultural context of a growing European community beyond the competition paradigm in the realm of education (Münch, 2010). From a policy perspective, the overview which follows does not aim at creating the format of a "European super teacher", but intends to indicate European issues that are potentially of particular significance in future discussions.

a) European identity: The question of who Europeans are and what has led to European identity can be answered from different angles (Checkel \& Katzenstein, 2009). Since the 1980s, the identification with Europe has become more politicized through the formation of the EU. Exchange programmes, scholarships and other transnational initiatives have taken teachers "beyond" the national curriculum. He/she would see himself/herself as someone with roots in one particular country, but simultaneously belonging to a greater European whole (Hilligus \& Kreienbaum, 2007). This co-existence of national identity and transnational awareness provides a valuable perspective on questions of heterogeneity. Diversity within unity is, therefore, a key aspect of a developed European identity with an open mind toward the world at large.

b) European knowledge: European knowledge can be viewed from different perspectives. On the governance level, there is knowledge about Europe that is 
expected from an educated European citizen and is already taught at primary level (see, for example, Hatzky \& Struve, 2005). On the higher education level, there is debate regarding "a Europe of knowledge", which has reflected the synergies and tensions between European research and higher education policies (see, for example, Chou, 2014). In the realm of teaching, the question arises of whether a European Teacher has to have some knowledge of other European education systems and, possibly, of educational policy matters on the EU level. Does s/he value his/her own education system and view it in relation to other European ones? Does s/he have a knowledge of European and world affairs and is s/he aware of European history (histories) and its (their) influence on contemporary European society?

c) European multiculturalism: A European Teacher engages with the multicultural nature of European society. He/she has an active relationship with his/her own culture and is open towards other cultures. He/she knows how to behave in other cultures in a confident and non-dominant way. He/she works with heterogeneous groups, sees heterogeneity as valuable and respects any differences. $\mathrm{He} / \mathrm{she}$ copes with the challenges of the multicultural aspects of the knowledge society and works to promote equal opportunities.

d) European language competence: A European Teacher speaks more than one European language with differing levels of competence. He/she experiences other languages in initial and further teacher education and is able to teach subjects in languages other than his/her first language. He/she spends some time in a country with a language different from his/her first language, and also communicates in a number of languages with colleagues and people from abroad.

e) European professionalism: A European Teacher has an education that enables him/her to teach in any European country. He/she has a "European" approach to subject areas in his/her teaching and links up cross-curricular themes from a European perspective. He/she exchanges curricular content and methodologies with colleagues from other European countries. He/she pays attention to and learns from different teaching and learning traditions. He/she uses examples of research from other countries to understand and explain professional issues and teaches accordingly.

Influenced by European initiatives (research, publications, expert groups, etc.) in many countries, teacher education has been inspired by a new professionalism with a European perspective (e.g. it does not restrict teaching practice to national boundaries) embracing the value of Bildung (Girmes, 2012). The German word Bildung, which has its origin in the educational school of Greek society, was adopted in Humanism and Enlightenment until it "became one of the central of the modern Western educational tradition. Central to this tradition 
is the question of what constitutes an educated or cultivated human being" (Biesta, 2006, p. 100).

Many teaching subjects already build on the rich history of the European tradition, and this can be usefully exploited. Joint programmes and degrees offered by educational institutions in European countries can enhance the development of European professionalism, as can many of the opportunities offered by modern technology.

f) European citizenship: A European Teacher should act as a "European citizen". $\mathrm{He} / \mathrm{she}$ should show solidarity with citizens in other European countries and shares values such as respect for human rights, democracy and freedom. His/ her critical teaching should foster autonomous, responsible and active citizens of a Europe of tomorrow. Aspects of the school curriculum may be developed in a teaching area, possibly entitled "European Studies", or "Europeanness" could be integrated across the curriculum.

g) European quality measures: If there is something like a European Teacher, there must be some way of comparing the formal features of Europe's teacher education systems. Suggestions reach from formal assessment of systems to informal exchanges and cross-cultural visits. The Bologna process is a major step towards academic comparability and achieving an overarching qualification framework across Europe. An increase in compatibility between European qualifications and in transparency of graduate achievement is central to the Bologna/Copenhagen processes, and would also remove obstacles from teacher mobility.

\section{Easy mobility as an added value of expanding teacher professional identity with the European dimension}

As an ideal, a European Teacher experiences the benefits of the European Union in part through easy mobility. This mobility encompasses studying abroad and learning languages as well as becoming acquainted with the cultures of other EU countries. He/she may seek employment in other countries and use exchange programmes offered by the European Union. This contributes towards the creation of a Europe of different languages and cultures, and nurtures cultural diversity as a vision for living together in the future.

A European Teacher facilitates mobility among his/her students by enabling them to have physical and virtual contact with peers in other European countries. Classroom or school exchanges and EU programmes are means to enrich the process of mutual learning and growing toward a new understanding of European citizenship. This helps in preparations for Europe-wide employability and, eventually, workplace mobility. 
Modern information and communication technologies (ICT) enhance mobility by offering useful tools for communicating across linguistic and cultural borders, enlightening the staid and predictable classroom routines produced by monocultural approaches. Virtual mobility in finding and disseminating information is seen as a vital prerequisite for physical mobility and is also very effective in transnational communication. European identity builds on the future citizens of the European Union. Therefore, the notion of the European Teacher can increase the students' practical knowledge of transnational issues and intensify their experience with intercultural encounters.

The diversity and multicultural make-up of schools can help children feel at home with Europe's developing complexity and pluralism. It is part of the teacher's role to prepare students for community life and work. Learning about multicultural values means acquiring an extensive general and artistic culture, learning foreign languages and developing some knowledge of European and world affairs.

A European Teacher who has experienced the value of mobility encourages students to develop this general culture, along with a critical perspective, so that they may become autonomous, responsible and active citizens. This culture forms the basis for the acquisition of skills that enable students to move around, live and work in different European cultures. As well as familiarity with different cultures, a European Teacher also needs to be able to analyse complex intercultural issues in order to enhance cross-cultural learning processes.

\section{Policy Development}

During the Portuguese Presidency of the EU in 1999, ENTEP was created to promote cooperation among European Union Member-States regarding their role in initial, in-service and further teacher education policies, in order to contribute to:

- Raising teacher education quality so as, in turn, to raise the quality of education and training in the European Union in a way that responds to the challenges of lifelong learning in a knowledge-based society.

- Developing a European dimension of education in teacher education programmes.

- Improving the public image of the teaching profession and mutual trust in the teaching qualifications awarded by Member-States.

- $\quad$ Promoting teacher mobility in the European Union (Gassner, 2012, p. 14).

Since ENTEP has taken an active role in dealing with those and other issues with a transnational perspective for fifteen years, the question of what 
constitutes a European Teacher has increasingly became an issue. However, beyond ENTEP, it could be a starting point for further discussions about future roles of teachers in Europe and could contribute to policy issues on different levels towards a European development of teacher professionalism. With this perspective in mind, the following areas can be regarded as relevant to be explored on various levels.

a) European level

- European qualifications framework ${ }^{6}$

- Common European Principles ${ }^{7}$

- Recommendations to member states in teacher education ${ }^{8}$

- European programmes (SOCRATES) ${ }^{9}$

b) National

- Content of teacher education programmes

- Definitions of competences and how they are evaluated

- Evaluations of initial/continuing progressive development (What is evaluated?)

- Accreditations of studies in other European countries

- How to use European programmes bilaterally

c) Institutional

- Institutional policies on European/international cooperation

- How to ensure "ownership" of projects at institutional level

- How to promote mobility programme and ensure credits/recognition

- Joint programmes, masters/doctorates

- Content of programmes

Through the participation in various working groups within the different European programmes and exchanges, the representatives from the individual member states have acquired new knowledge on the topics above, which has contributed to an increased transnational understanding towards Europe as a "knowledge society". Therefore, teacher quality can no longer be seen as a national affair, but rather as a topic of international cooperation and research.

6 See http://ec.europa.eu/ploteus/en/content/descriptors-page

7 See http://www.atee1.org/uploads/EUpolicies/common_eur_principles_en.pdf

8 They are sent to member states, e.g. in form of so-called policy handbooks. For example, see http://ec.europa.eu/education/policy/school/doc/handbooko410_en.pdf

9 The Erasmus programme was an educational initiative of the European Commission to strengthen the European dimension of education at all levels such as the Comenius programme relating to primary and secondary education, the Erasmus programme relating to higher education, the Grundtvig programme relating to adult education, the Lingua programme relating to education in European languages and the Minerva programme relating to information and communication technology in education. 
Among the various aspects of European dimensions in the education arena, the question of the meaning of the term "European Teacher" remains. Many discussions on this controversial issue have helped to stimulate further elaborations on this topic.

Such discussions, meanwhile, lead to a transnational review of some of the areas mentioned above by ENTEP which revealed:

- disparity across EU teacher education lifelong curricula due to a range of organizational, cultural and pedagogical issues;

- $\quad$ problems for mobility of teaching professionals, due to discretion on the type of doctoral programmes offered by institutions between and within countries;

- $\quad$ obstacles for teaching professionals to enter education science $\mathrm{PhD}$ programmes, due to specific entry criteria;

- $\quad$ potential negligence of knowledge from the field in conventional $\mathrm{PhD}$ programmes.

\section{New approaches to the promotion of the European di- mension in teacher professionalism}

As a consequence of the curricular disparities, mobility problems and obstacles to entry into $\mathrm{PhD}$ programmes, a consortium of five universities from the field of European higher education initiated the "European Doctorate in Teacher Education" (EDiTE) ${ }^{10}$ Project, which

- $\quad$ aims to develop an original, transnational and inter-disciplinary joint doctoral programme in teacher education;

- $\quad$ creates a closer link between practice and theory in teacher education;

- moves transnational research in teacher education nearer to national educational institutions;

- $\quad$ provides a forum for sharing theoretical knowledge and good practice from a European perspective;

- $\quad$ promotes standards, procedures and unifying principles for the design, organization and development of doctoral study programmes in teacher education (generative model).

10 The members of the consortium are University of Innsbruck, Austria (Lead Institution); Eötvös Loránd University, Budapest, Hungary; University of Lower Silesia, Wrocław, Poland; University of Lisbon, Portugal; University of Bucharest, Romania and ENTEP in the role of an advisory Board. This project has been funded with support from the European Commission (project number 527604-LLP-1-2012-1-AT-ERASMUS-EMCR). Duration: October 2012-September 2014. Further information on http://www.edite.eu 
The discussion of these issues among the members of the consortium was enriched by an ongoing consultation process with teacher education experts in Europe. By September 2013, 38 experts had been interviewed and asked about their expectations and aspects such as quality criteria, target group, job profiles, competences of graduates, research fields. These findings were used in the following curriculum design process.

The curriculum (180 ECTS) of the planned European Doctorate in Teacher Education is structured in two consecutive modules: The Advanced Studies Module: a comprehensive learning programme, consisting of three thematic sub-modules. 1) Advanced Pedagogical Studies, 2) Transversal Studies, 3) Research Methodology and Management; the Individual Research Module: an intensive research programme that creates a general framework for students to realise their individual research and makes their active involvement possible in relevant research on teacher education. EDiTE graduates become multipliers in their national, regional and local contexts, shaping new kinds of intersections between academic and vocational knowledge and competence.

\section{Conclusion}

A puzzling feature of teacher professionalism in European countries emerges from two widely shared assumptions that are contradictory and incompatible. The first is that contemporary teaching has become increasingly assimilated through the backwash effect of global large-scale assessment activities, such as PISA (Prenzel et al., 2013) under the new governance regime of evidence-based policy making (Gunter \& Fitzgerad, 2013) or through making teaching and learning more responsive through ground-breaking books such as Hattie's Visible Learning $(2009,2012)$, which seem to make teachers' professional work look very similar across country boarders. The second is that in the European educational field transnational activities of teachers and students increase steadily, but little has changed nationally with a cultural perspective towards Europe in mind (Seashore Louis \& van Velzen, 2012).

The argument has offered transnational perspectives on European teacher professionalism from various angles and has aimed at finding out about the "Europeanness" in teachers' work and mobility as a goal. In most countries, as an overarching theme, there seems to be a longing for creating a closer link between practice, policy and research with a view to innovative teaching in the context of the standards movement and new public management. If we compare the situation of the European Union with the composition of states in the USA, the notion of a "European teacher" will never come close to what 
is understood by an "American teacher". Nevertheless, this paper has shown that there is an interplay between European educational policy and a shared understanding of practice throughout the member states of the EU. What we can learn from each other to improve education is organizational learning facilitated by shared leadership, tight coupling and "boundary spanning" activities (Millward \& Timperley, 2010) across countries, within countries, between teacher education policy and the teaching profession.

\section{References}

Bauer, T. A., \& Ortner, G. E. (Eds.) (2008). Bildung für Europa: Politische Ansprüche und Anregungen für die Praxis. Paderborn: $\mathrm{B}+\mathrm{B}$ Medien.

Biesta, G. (2006). Beyond learning: Democratic education for a human future. Boulder: Paradigm Publishers.

Checkel, J. T., \& Katzenstein, P. J. (Eds.) (2009). European identity. Cambridge: Cambridge Univ. Press.

Chou, M.-H. (Ed.) (2014). Building the knowledge economy in Europe: New constellations in European research and higher education governance. Cheltenham: Elgar.

Craig, C. J., Meijer, P. C., \& Broeckmans, J. (Eds.) (2013). From Teacher Thinking to Teachers and Teaching: The Evolution of a Research Community. Bingley: Emerald.

Gassner, O. (2010). ENTEP and European teacher education. Policy issues since 2000. In O. Gassner, L. Kerger, \& M. Schratz (Eds.), The first ten years after Bologna (pp. 13-42). București: editura universitãţii din bucureşti.

Gassner, O., Kerger, L., \& Schratz, M. (Eds.) (2010). The first ten years after Bologna. București: editura universitãţii din bucureşti.

Girmes, R. (2012). Der Wert der Bildung: Menschliche Entfaltung jenseits von Knappheit und Konkurrenz. Paderborn: Schöningh.

Gunter, H. M., \& Fitzgerald, T. (2013). New Public Management and the modernisation of education systems 1. Journal of Educational Administration and History, 45(3), 213-219.

Hattie, J. (2008). Visible learning: A synthesis of meta-analyses relating to achievement. London: Routledge.

Hattie, J. A. C. (2012). Visible learning for teachers: Maximizing impact on learning. London, New York: Routledge.

Hatzky, I., \& Struve, D. (2005). Ich lerne Europa kennen: Fragen \& Antworten, Rätsel \& Lösungen.

Einfach schlau! Scheidegg: Media-Verlagsgesellschaft.

Heidenreich, M. (Ed.) (2014). Krise der Europäischen Vergesellschaftung? Dordrecht: Springer. Hilligus, A. H., \& Kreienbaum, M. A. (Eds.) (2007). Europakompetenz-durch Begegnung lernen. Opladen: Budrich.

Millward, P., \& Timperley, H. (2010). Organizational learning facilitated by instructional leadership, 
tight coupling and boundary spanning practices. Journal of Educational Change, 11(2), 139-155. Münch, R. (2008). Die Konstruktion der europäischen Gesellschaft: Zur Dialektik von transnationaler Integration und nationaler Desintegration. Frankfurt am Main: Campus-Verlag. Münch, R. (2010). Bildung als Teil des Wettbewerbs-Paradigmas der Europäischen Union: Das Ineinandergreifen von OECD-Agenda, Lissabon-Strategie und nationaler Reformpolitik. In H.-J. Blanke, A. Scherzberg, \& G. Wegner (Eds.), Dimensionen des Wettbewerbs. Europäische Integration zwischen Eigendynamik und politischer Gestaltung (pp. 127-144). Tübingen: Mohr Siebeck.

Prenzel, M., Kobarg, M., Schöps, K., \& Rönnebeck, S. (2013). Research on PISA: Research Outcomes of the PISA Research Conference 2009. Dordrecht, New York: Springer.

Schratz, M. (2010). What is a "European Teacher"? In O. Gassner, L. Kerger, \& M. Schratz (Eds.), The first ten years after Bologna (pp. 97-102). București: editura universitãţii din bucureşti.

Schratz, M., Paseka, A., \& Schrittesser, I. (Eds.) (2011). Pädagogische Professionalität: quer denken umdenken - neu denken: Impulse für next practice im Lehrerberuf. Wien: Facultas.wuv.

Seashore Louis, K., \& van Velzen, B. (Eds.) (2012). Educational policy in an international context: Political culture and its effects. New York: Palgrave Macmillan.

Senge, P. M. (1990). The fifth discipline: Mastering the five practices of the learning organization. New York: Doubleday/Currency.

Snoek, M., Uzerli, U., \& Schratz, M. (2008). Developing Teacher Education Policies through Peer Learning. In B. Hudson \& P. Zgaga (Eds.), Teacher Education Policy in Europe: a Voice of Higher Education Institutions (pp. 135-156). Umeå: Faculty of Education, 2008.

Valenčič Zuljan, M., \& Vogrinc, J. (Eds.) (2011). European dimensions of teacher education: Similarities and differences. Ljubljana, Kranj: Faculty of Education; The National School of Leadership in Education. 


\section{Biographical note}

Michael Schratz, dr., is a Professor of Teacher Education and School Research, University of Innsbruck, Austria, and a Research Director for Teaching, Learning and Leadership, at the National Leadership Academy. As the present Dean of the School of Education he is responsible for teacher education reform programs nationally and internationally and has been policy consultant for various governments. He is the present Speaker of the Jury of the German School Award. His main research projects are in educational leadership, learning and teaching as well as policy development. His publications have been translated into several languages. 